\title{
A review on investigation of water-preserved coal mining in western China
}

\author{
Limin Fan $^{1,2} \cdot$ Xiongde $\mathrm{Ma}^{3}$
}

Received: 14 November 2017/Revised: 26 July 2018/Accepted: 3 September 2018/Published online: 8 November 2018

(C) The Author(s) 2018

\begin{abstract}
Yushenfu mining area is located in an ecological fragile area in western China, the coal seam of which is the Jurassic Yan'an Formation. The Jurassic Yan'an Formation contains five minable coal seams, the top layer of which is thick, covered by shallow overburden and located under aquifers. Therefore, the mining induced water flowing fractured zone can easily extend to the aquifers of both the Quaternary Sarahu and Jurassic Zhiluo Formation. This would result in a series of negative hydrological and ecological effects, including groundwater leakage, groundwater lowering, furtherly causing surface vegetation withering and dying, surface water body reduction, spring drying out, and water flow of river being decreased substantially. To solve these environmental problems, several technologies have been carried out by Chinese scientists, one of which is water-preserved coal mining. This paper presents a review of the origin, definition and development of water-preserved coal mining, and its applications in Yushenfu mining area. The applicable conditions, research contents, research methodology, and technical foundation of water-preserved coal mining are addressed in this paper. The future research focuses regarding water-preserved coal mining in China are also discussed in this paper. Its results serve as a guide for selecting the methods to be preferred for mining in case the geological conditions, roof overburden structure and coal mining process are similar to Yushenfu mining area.
\end{abstract}

Keywords Water-preserved coal mining (WPCM) Ecological water table $\cdot$ Ecological fragile mining areas $\cdot$ Western China $\cdot$ Water conducting fissure zone

\section{Introduction}

Yushenfu mining area of Jurassic coal field is located in the west of China, more specifically, the southeastern margin of the Ordos basin, which is a transition zone between the Musu desert and the Shanbei plateau. Two of 14 major coal

Limin Fan

fan19880629@163.com

1 Key Laboratory of Mine Geological Hazard Mechanism and Control, Ministry of Land and Resources, Xi' an 710054, China

2 Shaanxi Institute of Geo-Environment Monitoring, Xi' an 710054, China

3 College of Environmental Science and Engineering, Chang' an University, Xi' an 710054, China bases of China are located in this area, Shanbei and Shendong coal bases. The Yushenfu mining area is about $8900 \mathrm{~km}^{2}$, with proven coal reserves of more than 140 billion tons. The development of this mining area, started from 2000, are divided into 4 stages, with mining area of $873,1098,864$ and $2430 \mathrm{~km}^{2}$ at each stage, respectively. By the year of 2015, 149 coal mines have been constructed with a total annual production of over 1 billion tons.

At the beginning of mine development, lacking of thorough consideration of the geological environment constraints, unreasonable layout of the mine planning have resulted in a series of negative environment impacts (Fan 1992). For instance, the groundwater table dropped (Fan et al. 2016), the water quality deteriorated, surface water and wetland decreased (Ma et al. 2015), arable lands, forest and grasslands were destroyed by a large number of surface cracks (Bi et al. 2014), landslide collapsed and mining- 
induced seismicity occurred (Ji et al. 2015). Those environment damages have been drawing a lot of social concerns.

In order to reduce the negative environment impacts of mining, Fan $(2005,2017)$ has proposed a method to protect environment while coal mining, namely, Water-preserved Coal Mining (WPCM). The main idea of this method is to rationally divide the mining area into different subareas and apply different mining methods to different mining subareas to achieve the goal of water protection while mining coal (Wu et al. 2017; Wang et al. 2010).

This paper is to review the concept, technical foundation and application of WPCM technology in Yushenfu mining area.

\section{Research progress of WPCM}

\subsection{Problems}

The full development of coal mining in Yushenfu mining area began in the late 1980s. As the increasing knowledge of the hydrogeology and environmental geology in this mining area and understanding of practical problems encountered during coal mining, the environmental problems associated with coal mining have been drawing more and more attentions from scientists. The problems include water loss and environmental degradation, which could in turn bring safety issues to the mine. This is evidenced by two roof fall accidents occurred in Ciyaowan coal mine of Shenbei mining area on April 28 and December 20, 1990, respectively. Due to the thickness of bedrock aquiclude is less than $100 \mathrm{~m}$, the mining induced water flowing fractured zone extended to the aquifers of the Quaternary Sarahu, which caused water inrush. Although the amount of mine water inrush was small, a large amount of sand inrush into the roadway resulted in belt lane was filled by sand, continuous groundwater table dropping, drying of reservoirs, reduction of spring flow, and vegetation withering (Ma et al. 2017).

Therefore, protection of groundwater during coal mining in ecological fragile areas is important for both environmental protection and mine safety (Fan 1992). Groundwater resources should be protected during coal mining (Han et al. 1992). A new concept of water-preserved coal mining is proposed by Fan (2005), which uncovered the prelude of research on water protection while coal mining.

\subsection{The concept of water-preserved coal mining}

The Yushenfu mining area is located in an arid and semiarid region of average annual precipitation about $400 \mathrm{~mm}$. The water resources in this area are limited and are unevenly distributed in different areas and through different time in a year. Groundwater is the only water source for industry, agriculture, human and animals consumption, and ecological systems. However, the past coal mining activities broke the overburden of the coal seams and damaged the water conducted zone, resulting in unstable bottom structures of the aquifers. The water resource balance was then broken because the aquifers of water supply significance lost water storage capabilities. Therefore, scientists started to focuse on the maintenance of the stability of ecological valuable aquifers. It is important to implement proper ideas and methods to mine planning, mine design, and mine development to ensure the harmonious development of resources and environment.

The aim of water-preserved coal mining is to maximize the social and economic efficiency. WPCM refers to the technology to seek the best solution to balance coal mining efficiency and water carrying capacity in arid and semi-arid area. The solution is to be achieved by controlling the movement of rocks to maintain the stability of aquifers of water supply significance and ecological values or by controlling the changes of water table within a reasonable range.

The research objects of water-preserved coal mining are aquifers of water supply significance and ecological values in the western arid and semi-arid areas. Based on ground control theories and technologies, coal mining technologies can be developed to control the development of water conducting fissure zone. The main study objects are the structures and the water level of aquifers. The structure of aquifers should be stable or could still restore water for a certain time in the situation of being destroyed. The purpose of water-preserved coal mining is to balance the supply and demand between coal resources and water resources, to achieve the resource development and water protection simultaneously.

The protection aquifers of water-preserved coal mining are aquifers of Quaternary Salawusu formation $\left(\mathrm{Q}_{3 \mathrm{~S}}\right)$ and Jurassic Yan'an formation $\left(\mathrm{J}_{2} \mathrm{y}\right)$ (Fan et al. 2016) in the north of Ordos basin, Ordovician Karst in the south of Ordos basin (Ma et al. 2016), and Cretaceous Luohe formation in the west and southwestern margin of Ordos basin. The aquifers which have significant contributions to the base flow of rivers, aquifers which have important effects on vegetation succession, surface reservoir, and deep aquifers should also be included in the system of water-preserved coal mining.

\subsection{The research category of water-preserved coal mining}

The research of water-preserved coal mining focuses on four aspects, survey, analysis, and assessment of geological 
conditions, stability study of aquicludes, constraint conditions of ecology, and methodologies of water-preserved coal mining.

\subsubsection{Geological survey}

The study of geological and hydrogeological conditions is the basis of water preserved coal mining. The mining area is divided into water rich and water poor subareas according to the survey of geological conditions, geological structure, water bountifulness of the aquifers and rechargeable condition of the area. Coal should be mined by highly mechanized mining technology in water poor mining areas while the water preserved coal mining technology should be implemented in waterrich mining areas. The current geological data (Fan 1992) shows that the hydrogeological conditions of Yushenfu coal mining area can be divided into four categories, namely isolated small water rich basins, large aquifers without a clay aquifuge, aquifers with a stable clay aquifuge and SalaWuSu-burnt rock aquifers. However, due to the area variability of geological conditions and inadequate drilling holes, the accurate knowledge of geological conditions is absence within each partition. For each working face, detailed geological conditions should be explored through exploration drilling, geophysical exploration, and geochemical exploration. In 2015, the water rich burnt rock area of $5^{-2}$ coal seam of Hongliulin coal mine was determined through geophysical exploration, which provided a support for implementing water-preserved coal mining technology.

The normally used empirical formulas to predict the height of water conducting fissure zone originate from «Regulations of buildings, water, railway and main well lane leaving coal pillar and press coal mining» and «Mine Hydrogeology Regulations» (Hu et al. 2012). However, height of water conducting fissure zone is highly influenced by various factors such as geological conditions, roof overburden structure and coal mining process. More and more researches have focused on correction of the empirical formula by validating the height of the water conducting fissure zone, or to propose a new formula for predicting the height of water conducting fissure zone.

The multi-factor weighted evaluation model which based on geological and hydrogeological conditions is a direct method of risk prediction for water and sand inrush. This method also relies on detailed geological data with spatial analysis of GIS to predict the possibility of water and sand inrush during coal mining. This method is also able to determine the key areas of implementing waterpreserved coal mining technology.

\subsubsection{Structure stability of aquifuges}

The aquifuges of Yushenfu coal mining area are mainly overlying bedrocks (siltstone) and clay (yellow and red clay) (Huang et al. 2010; Huang 2003). The thickness of bedrock aquifuges is normally less than $150 \mathrm{~m}$ and the thickness/load ratio of bedrock is no more than 1 (Huang 2002). The coal seam is shallow and bedrocks are thin, thus the working face bears large dynamic loadings which could result in step subsidence. The collapse of overlying rocks only exists in "two zones", namely water conducting fissure zone and fractured zone, and the fragmentation degree of overburden rock is large. If the clay layers are absent in overlying bedrocks, the "two zones" will directly contact with the aquifer. The structure of aquifuge will be completely destroyed, causing loss of water. If there is a clay layer in the overlying bedrocks, whether the "two zones" will penetrate into the clay layer depends on the thickness and mechanical properties of the layer.

The evolution characteristic of water-resisting property of clay during mining has been a key point in water-preserved coal mining, the study which is still insufficient. According to the water-resisting property change of clay caused by strata displacement and deformation, Liu (2016) divided the evolution of water-resisting property of clay into three stages, impermeability keeping stage, impermeability decreasing stage, and impermeability losing stage. Huang et al. (2010) stated that the breaking of bedrocks is the main factor that influence development of the "upward fissures", while the hydrological properties of clay are the main factors that influence close of "downward fissures". The relationship between "upward fissures" and "downward fissures" determined the stability of the aquifuges impermeability.

\subsubsection{Constraints of groundwater level on coal mining}

The constraints of groundwater level on coal mining in arid and semi-arid areas are represented by two aspects, water table and water quantity. Water table is related to ecological value and river base flow (Liu and Zhang 2006). Water quantity is related to available exploitation capacity of groundwater. Previous researches (Yang et al. 2006; Wang et al. 2008) have shown that the relationship between river baseflow and groundwater table is linear. Thus to ensure the sustainably development of regional ecological environmental, coal mining must meet the requirement of a certain water table threshold. The upper limit is to reduce evaporation amount of phreatic water and the lower limit is to sustain virtuous development of an ecological system. To achieve this threshold, the only way is to control movement and deformation of the overlying rocks and 
control water resources by implementing water-preserved coal mining technology (Ma 2016).

\subsubsection{Water-preserved coal mining technology}

Restraining the height of fissure zones is an effective way to realize water-preserved coal mining. The drilling results from YuShen mining area showed that under general conditions, the ratio of the height of the fissure zones to the mining height is between 20 and 26 (Miao and Jiang 2014). In the case that thickness of the overlying rocks is less than height of fissure zones, water-preserved coal mining technologies could be applied using the following techniques.

(1) Backfilling coal mining. The mixture of both water and sand is used to fill the mined areas to reduce the space of gob area and reduce the height of fracture zone (Xu et al. 2007).

(2) Narrow strip coal mining. This method applies for small mines. The width of the working face is reduced by reserved pillars, thus reduce the height of water conducting fissure zone (Shao et al. 2014).

(3) Slice mining. Based on the distribution of thick coal seams in Yushenfu coal mining area (Wang et al. 2015), mining height was reduced to control the height of fissure zones (Wang et al. 2014a, b).

(4) Longwall mining by speeding face advance rate. In some of the coal mines in the Shendong mining area, the height of water conducting fissure zones can be reduced through increasing face advance rate (Ma et al. 2008, 2014).

\section{Engineering practice of water-preserved coal mining technology}

\subsection{Protection of overlying aquifers}

\subsubsection{Backfilling}

The backfilling mining is an effective method for roof control which is beneficial to both environmental protection and coal mine safety. Backfilling is widely applied in room and pillar mines and longwall mines. The backfilling method provides a technical approach for aquifer protection and rock movement control.

The Yuyang coal mine implemented water preserved coal mining by filling aeolian sands in the mine (Lv 2013). The filling materials are mainly aeolian sands, fly ash, cement, special auxiliary materials and water of certain percentages. The percentages of water is less than $35 \%$ (paste-like fill). 50 entries of No. 2301 working face have been filled with a total volume of $52000 \mathrm{~m}^{3}$. The strength of filling bodies after 28 days reached $5.30 \mathrm{MPa}$. The filling ratio was between $50 \%$ and $70 \%$. After the backfilling, the surface subsidence decreased by more than $50 \%$. Geological survey showed that the water tables decreased by about $0.45-2.76 \mathrm{~m}$ and the depths of water table was controlled in the range of 4-6 m.

Local backfilling and limited height mining have also been carried out in some coal mines of Shendong mining area. The main approach is to reduce mining height properly or partially fill the areas near the open-off cuts of working faces and the recovery line.

\subsubsection{Narrow strip coal mining}

In narrow strip coal mining, the mining system is arranged according to the original longwall mining system. The original longwall face is divided into a number of mining strips which are parallel to the original open-off cuts (Shao et al. 2009). When mining each strip, the working face is developed between the head entry and tail entry. After an exhaust ventilation system is formed, retreating mining is then conducted in the mine.

The narrow strip coal mining has been conducted in about 10 coal mines of the Yuyang District. A working face was divided into 20 strips, with 12 strips mined and 8 strips reserved in the mines. The recovery rate of narrow strip coal mining was increased by $20 \%$ or more compared to room and pillar mining method. The production of a single mine was increased to 1-3 million tons.

\subsubsection{Slice longwall mining (limited mining height)}

Two mining methods are normally applied in mining thick coal seams, cave mining and slice longwall mining (Wang et al. 2014a, b). Though high efficiency, overlying rocks are seriously damaged and overburden stress are increased intensely in cave mining. It has shown in practice that reducing initial mining thickness and increasing repeated mining thickness can effectively reduce the height of water conducting fissure zones and mining cost. Proper design of thickness of initial mining and repeated slice longwall mining can prevent damage of overlying aquifers.

The Yushuwan coal mine contains 5 coal seams. The top coal seam, No. $2^{-2}$ coal seam, is $11 \mathrm{~m}$ thick which could be mined by slice mining. Results of numerical simulation (Wang et al. 2014a, b) showed that the groundwater in over $45 \%$ area of the Sarahu Formation would be lost if the initial mining height exceeds more than $7 \mathrm{~m}$ using cave mining method. However, water preserved coal mining can be realized in most areas if the height of the upper slice is about $5 \mathrm{~m}$. The drilling data (Miao and Jiang 2014) showed that the water conducting fissure zones has not reached up to the aquifer of Salawusu Formation when the mining 
height of the upper slice of Yushuwan coal mine was designed to be $5.5 \mathrm{~m}$. This provides evidence that Yushuwan coal mine achieved water preserved coal mining.

\subsubsection{Longwall mining by increasing face advance rate}

The coal seam in Bulianta coal mine of Shendong coal mine area is shallow covered by overlying bedrocks. To implement water-preserved coal mining in Bulianta coal mine, three measurements were applied in 32201 working face and 32202 working face. These measurements included increasing face advance rate, limiting mining height or partially backfilling, and utilizing a reasonable support resistance in the key areas. These measurements effectively reduce the damage of roof bedrocks and avoid full development of water conducting fissure zones. Both field survey and numerical simulation (Ma et al. 2008, 2014) showed that the change of water table was small, with decline of groundwater level larger than the subsidence only at the two sides of the working face. The results indicated that the Salawusu formation aquifer was protected effectively.

\subsection{Protection of aquifer for coal seam floor}

The Chenghe mining area of Weibei coal field is located in western China. Under the coal seams of this area is a water rich Ordovician limestone aquifer, the water table of which is $375 \mathrm{~m}$ uniquely. The Ordovician limestone aquifer is an important water source for industrial and agricultural water supply in Weibei district and is the key recharge source for the wetlands in the Weibei area. However, the Ordovician limestone aquifer also brings water inrush hazards for mining to this area (Pang et al. 2014). The protection of this aquifer is of significant importance. Therefore, it is necessary to carry out WPCM in Weibei coalfield to ensure safe coal mining and maintain the water table stability.

The water inrush coefficient in Dongjiahe coal mine is $0.13-6.0 \mathrm{MPa} / \mathrm{m}$ when the mining height is $4 \mathrm{~m}$. According to the "Rule of mine prevention and cure water disaster" (Wu et al. 2011), the critical threshold value of water inrush coefficient is $0.06 \mathrm{MPa} / \mathrm{m}$ in an area with tectonic damage. Since the water inrush coefficient is higher than $0.06 \mathrm{MPa} / \mathrm{m}$ in $43 \%$ of the mining areas, the Donajiahe coal mine is considered as a risk zone of mining under pressure. In order to solve the problems associated with mining under pressure, Donjiahe coal mine built a waterresisting floor grouting system to enhance the strength of coal seam floor, which is the largest in China. Using direct current method to detect the water bearing property, the floor grouting showed an excellent effect to improve the water bearing property and prevent water inrush caused by aquifers.

\section{The future research in water preserved coal mining}

There are four scientific problems that need to be solved in water preserved coal mining.

(1) A fluid-solid coupling model to study the evolution of compressive strength and variation mechanism of permeability in rocks needs to be built. A fluid-solid coupling equation based on stress equilibrium equations and seepage continuity equations should be established to determine the fissure flow. This equation should also be able to solve the expansion, deformation, and evolution problems for initial fissures and mining fissures under water pressures.

(2) Theories and methods to evaluate groundwater and ecology constraints in mining areas based on evapotranspiration mechanism of groundwater and unsaturated zones in arid and semiarid sandy areas should be established. The main focuses of this method are to study the water absorption characteristics of typical plants in arid environment, the optimum depth of water table to reduce the evaporation rate of stable sand, and the reduction of ineffective evaporation.

(3) Deep study should be conducted on characteristics of movement, deformation and collapse of shallow coal seams with thin overlying bedrocks. The study can build a foundation for computing the height of the water conducting fissure zones. A new empirical formula should be further built to compute the height of water conducting fissure zones according to the geological structure and rock mechanics in the areas.

(4) A low cost and high efficiency backfilling mining technology should be developed. Utilizing this technology, shallow coal seams would be efficiently mined while the aquifers are protected to ensure the environmental protection in the shallow coal seam mining areas.

\section{Conclusion}

The Jurassic Yan'an Formation of Yushenfu coal mining area contains five minable coal seams, the top layer of which is thick, covered by shallow overburden and located under aquifers. Therefore, the mining induced water flowing fractured zone can easily extend to the aquifers of both the Quaternary Sarahu and Jurassic Zhiluo Formation. This would result in a series of negative hydrological and ecological effects. To solve these environmental problems, several technologies have been carried out by Chinese 
scientists, one of which is water-preserved coal mining. The main idea of this method is to rationally divide the mining area into different subareas and apply different mining methods to different mining subareas to achieve the goal of water protection while mining coal.

The research of water-preserved coal mining focuses on four aspects, including survey, analysis, and assessment of geological conditions, stability study of aquicludes, constraint conditions of ecology, and methodologies of waterpreserved coal mining. The commonly used water-preserved coal mining technology are backfilling coal mining, narrow strip coal mining, Slice longwall mining and Longwall mining by increasing face advance rate. Owing to the good performance of these methods, the review also floats a suggestion for future investigation to develop more effective methods to ensure the environmental protection in the shallow coal seam mining areas.

Acknowledgements This work was supported by the National Key Foundation (973) Research Program (No.2 013CB227901) and Science and Technology Extension Program of Shaanxi (No. 2011TG$01)$.

Open Access This article is distributed under the terms of the Creative Commons Attribution 4.0 International License (http://crea tivecommons.org/licenses/by/4.0/), which permits unrestricted use, distribution, and reproduction in any medium, provided you give appropriate credit to the original author(s) and the source, provide a link to the Creative Commons license, and indicate if changes were made.

\section{References}

Bi Y, Zou H, Zhu C (2014) Dynamic monitoring of soil bulk density and infiltration rate during coal mining in sandy land with different vegetation. Int J Coal Sci Technol 2:198-206

Fan L (1992) Environmental geology in Shenmu mining area. Hydrogeol Eng Geol 6:37-40

Fan L (2005) Discussing on coal mining under water-containing condition. Coal Geol Explor 5:53-56

Fan L (2017) Scientific connotation of water-preserved mining. J China Coal Soc 1:27-35

Fan L, Xiang M, Peng J (2016) Groundwater response to intensive mining in ecologically fragile area. J China Coal Soc 11:2672-2678

Han S, Fan L, Yang B (1992) Some hydrogeological and engineeringgeological problems concerning development of north Shaanxi Jurassic Coalfield. Coal Geol China 1:49-52

Hu X, Li W, Cao D, Liu M (2012) Index of multiple factors and expected height of fully mechanized water flowing fractured zone. J China Coal Soc 4:613-620

Huang Q (2002) Ground pressure behavior and definition of shallow seams. Chin J Rock Mech Eng 8:1174-1177

Huang Q (2003) Simulating test on damage regularities of thick sandy soil layer and load distribution on key roof block in shallow coal seams. Coal Geol Explor 6:22-24

Huang Q, Wei B, Zhang W (2010) Study of downward crack closing of clay aquiclude in shallow-buried coal seam. J Min Saf Eng $1: 35-39$
Ji R, Peng S, Fan L, Zhao Y, Li C (2015) Effect of coal exploitation on groundwater circulation in the Shen-Fu mine area: an example from middle and lower reaches of the Kuye river basin. J China Coal Soc 4:938-943

Liu S (2016) Study on mining failure law of overburden and mining instability mechanism of clay waterproof layer in thick coal seam. China University of Mining and Technology, Beijing

Liu X, Zhang Y (2006) Essence and indicators of the healthy Yellow River. J Hydraul Eng 6:649-654

Lv W (2013) The application of the backfill mining in Yu-yang coal area. Sci Technol Innov Herald 33:45-48

Ma L, Zhang D, Liu Y et al (2008) Aquifer-protective mining technology in shallow coal seam with thin bedrock. J Hunan Univ Sci Technol (Nat Sci Edi) 1:1-5

Ma L, Sun H, Wang F et al (2014) Analysis of the ground water level change of aquifer protective mining in longwall coalface for shallow seam. J Min Saf Eng 2:232-235

Ma X, Fan L, Zhang X et al (2015) Driving force analysis for water and wetlands evolution at Yushenfu mining area. J China Coal Soc 5:1126-1133

Ma X, Du F, Qi P, Li W (2016) Technology and engineering practices on water preserved coal mining inseam with pressurized water floor. Coal Sci Technol 8:61-66

Ma X, Fan L, Yan G et al (2017) Vegetation responses to groundwater level change in mining area. J China Coal Soc 1:44-49

Miao J, Jiang Z (2014) Drilling detection of the height of water conducting fissure zone in fully mechanized mining face. Shaanxi Coal 6:33-36

Pang Y, Wang G, Ding Z (2014) Mechanical model of water inrush from coal seam floor based on triaxial seepage experiments. Int J Coal Sci Technol 4:428-433

Shao X, Shi P, Wang H (2009) Study on pillars stability by keeping water in strip mining for small and medium-sized mines in northern Shanxi Province. Coal Technol 12:58-61

Shao XP, Ding ZW, Zhang J (2014) Study on long time effect and replacement mining method for coal pillar in strip mining. Coal Eng 8:57-59

Wang Y, Wang W, Qian Y, Duan L, Yang Z (2008) Change characteristics and driving forces of base flow of Yellow River Basin. J Nat Resour 3:479-486

Wang S, Huang Q, Fan L et al (2010) Study on overburden aquclude and water protection mining regionazation in the ecological fragile mining area. J China Coal Soc 1:7-14

Wang W, Sui W, Dong Q (2014a) Influence of cover stress reestablishment on the permeability evolution of the mininginduced fractures. J China Coal Soc 06:1031-1038

Wang Y, Xia Y, Du R (2014b) Discussion on maximum mining height of coal mining under water-containing condition in one mine field of northern Shaanxi province. J Min Saf Eng 4:558-563

Wang J, Yu B, Kang H et al (2015) Key technologies and equipment for a fully mechanized top-coal caving operation with a large mining height at ultra-thick coal seams. Int J Coal Sci Technol 2:97-162

Wu Q, Zhao S, Li J et al (2011) The preparation background and the main points of Rule of mine prevention and cure water disaster. J China Coal Soc 1:70-74

Wu Q, Shen J, Wang Y (2017) Mining techniques and engineering application for "Coal-Water" dual-resources mine. J China Coal Soc $1: 8-16$

Xu J, You Q, Zhu W, Li X, Lai W (2007) Theorectical study of stripfilling to control mining subsidence. J China Coal Soc 2:119-122

Yang Z, Wang W et al (2006) Huang Jinting Research on buried depth of eco-safety about groundwater table in the blown-sand region of the Northern Shaanxi province. J Northwest Sci Tech Univ Agric For 8:67-74 